The Preemption War 
This page intentionally left blank 


\section{The Preemption War}

\section{When Federal Bureaucracies}

\section{Trump Local Juries}

Thomas O. McGarity

Yale University Press

New Haven \& London 
Published with assistance from the Louis Stern Memorial Fund.

Copyright (C) 2008 by Thomas O. McGarity.

All rights reserved. This book may not be reproduced, in whole or in part, including illustrations, in any form (beyond that copying permitted by Sections I07 and 108 of the U.S. Copyright Law and except by reviewers for the public press), without written permission from the publishers.

Set in Garamond and Stone Sans types by The Composing Room of Michigan, Inc.

Printed in the United States of America.

Library of Congress Cataloging-in-Publication Data

McGarity, Thomas O.

The preemption war : when federal bureaucracies trump local juries / Thomas O. McGarity. p. cm.

Includes bibliographical references and index.

ISBN 978-0-300-I2296-I (cloth : alk. paper)

I. Exclusive and concurrent legislative powers-United States. 2. Federal governmentUnited States. 3. Political questions and judicial power-United States. 4. Judicial review —United States. I. Title.

$\mathrm{KF}_{4} 600 . \mathrm{M}_{358} 2008$

$342.73^{\prime} \mathrm{O} 4-\mathrm{dc} 22$

2008021468

A catalogue record for this book is available from the British Library.

This paper meets the requirements of ANSI/NISO Z39.48-1992 (Permanence of Paper). It contains 30 percent postconsumer waste (PCW) and is certified by the Forest Stewardship Council (FSC). 
To my daughters, Kristi and Lauren 
This page intentionally left blank 